\title{
Evolving Values and How They Have Shaped the United States National Park System
}

\author{
Cari Goetcheus $^{a *}$, Nora J. Mitchell ${ }^{b}$, and Brenda Barrett ${ }^{c}$ \\ a College of Environment and Design, University of Georgia, Athens, United States

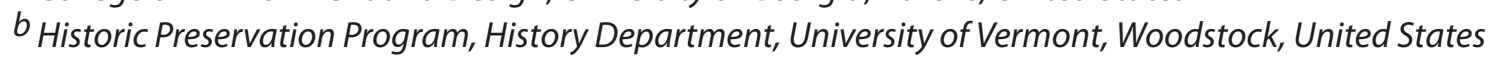 \\ c Living Landscape Observer, Harrisburg, United States \\ *Corresponding author: cgoetch@uga.edu
}

\begin{abstract}
As one of the oldest and best-known park systems, the US National Park System continues to influence park systems around the world. However, the origins and wide diversity of US national parks are often not fully understood as there is a long-lived misconception that the large western parks represent the entirety of the US National Park System. In fact, the establishment of the first US national parks was heavily influenced by large $19^{\text {th }}$-century picturesque urban parks that provided benefits to the public and society. The foundational concept of national parks serving a public purpose has never changed, however, the types of landscapes selected as national parks have changed as societal values have evolved and now the system provides public benefits beyond those originally envisioned. This paper examines the development of the US National Park System, emphasising the evolution of landscape values. The emergence of the cultural landscape concept illustrates the evolution of landscape values from their early antecedents in the late $19^{\text {th }}$ century to their contributions to innovative conservation strategies today. Throughout the development of the US National Park System, international exchange has and continues to play a pivotal role, advancing the inter-linkages of culture and nature for the most effective conservation.
\end{abstract}

KEYWORDS US National Park Service, US National Park System, cultural landscape, landscape values, interlinkages of culture-nature

Received July 23, 2018; accepted August 14, 2018.

\section{Introduction}

As one of the oldest and best-known park systems, the US National Park System continues to influence the development of national park systems around the world. However, the origins and wide diversity of US national park types are not fully understood. Often perceived at home and abroad as consisting largely of wilderness landscapes located in the American West, this is, however, a longlived misconception. In fact, the establishment of the first US national park was heavily influenced by large $19^{\text {th }}$-century picturesque urban parks, particularly New York City's Central Park, valued for the benefits their scenic qualities offered for the health and wellbeing of individuals and society. A recent study, The Olmsteds and the National Park System, more fully describes the impetus for the initial creation of national parks in the context of the Civil War, making important revisions to the conventional narrative about the origin and development of the US National Park System (Diamant et al. in press). The devastating fouryear Civil War (1861-1865) forged a fundamental transformation of American government and its purposes. In this context, creating parks in places such as Yosemite (in 1864) was an important part of a larger postwar national government agenda to redefine and expand the rewards of American citizenship.

This foundational concept of national parks serving an important public purpose has never changed; however, the types of landscapes selected as national parks have changed as societal values have evolved over the decades. Since the initial scenic western national parks were set aside, there has been a growing awareness of a wider array of landscape values and hence a dramatic increase in the diversity of landscapes in the US National Park System that reflects the nation's broad range of natural and cultural heritage (Manning et al. 2016). 
This paper briefly explores the evolution of the US National Park System over the past 150 years, highlighting key shifts from early park-making in scenic western landscapes in the mid- $19^{\text {th }}$ century, to archeological sites, battlefields and other historic places in the early $20^{\text {th }}$ century, to the growing concern for ecological and wilderness values in the 1960s and 1970s, to the recognition of cultural landscapes in the late 1980s, and to the large scale partnership-based parks of today. From this historical perspective, this paper argues that the emergence of cultural landscapes is not a recent phenomenon, but built upon previous recognition of the historic and cultural values of many national parks. National parks with archeological sites, battlefields, wilderness areas, along with those that had Native American or other communities as part of their history, in essence, served as prototypes for what would later be called cultural landscapes. The development of the cultural landscape field in the US benefitted from international exchange and conceptual frameworks from geographers (Sauer 1925; Jacques 1995). Development of recognition of cultural landscapes, in this paper, serves as an illustration of the broadening definition of national park values and attributes.

This paper also argues that the recognition of cultural landscapes has been particularly important in contributing to the field of conservation ${ }^{1}$ due, in part, because they embrace a wide array of interconnected cultural and natural values. The holistic, integrated perspective used in cultural landscape work is often termed a landscape approach' and is of value to conservation of many types of landscapes (Taylor et al. 2015, 372). In closing, this paper reflects on the societal benefits of a diverse National Park System and identifies some important new directions, arguing that awareness of the full range of landscape values is of utmost importance as a foundation for effective conservation. As international exchange played a key role in the development of the idea of national parks and their conservation, this paper argues for continuing such dialogue today and into the future.

\section{Evolution of Landscape Values Reflected in the Diversity of the US National Park System}

Today, the US National Park System is a complex and highly diversified assemblage of 417 national parks that have been legislatively protected for multiple objectives including dramatic scenery, history, artistic expression, ecological diversity, recreational opportunities, cultural landscapes, and wilderness values. Created in response to a 150-year evolving social context, the increasingly wide array of landscape values that define national parks has contributed to the diversity of the system today. As the chronological development of the park system is a complex story and beyond the scope of this paper, this section focuses on some of the pivotal moments in national park history that demonstrate significant expansion of the types of landscapes designated as national parks, focusing on cultural landscapes. This paper highlights the prominence of historical and cultural values that emerged very early in the history of the park system and continue to influence additions to the system today.

\section{The Early Years: Designation of Yosemite}

In 1864, the US Congress granted Yosemite Valley and the Mariposa Grove of giant sequoias (38,000 acres) to the State of California as a park 'for public use, resort, and recreation. Inalienable for all time' (Yosemite Valley Grant Act 1864). As this Yosemite Act represents the first significant reservation of public land by the US Congress to be preserved in perpetuity for the benefit of the entire nation, it has rightly been asserted, 'national parks were born at that moment' (Joseph Sax quoted in Diamant et al. in press, 19). Yosemite was preserved for its dramatic scenery and its antecedents can be found in Central Park in New York City, designed by Frederick Law Olmsted, Sr. and Calvert Vaux in the 1850s, drawing on European precedents of large urban picturesque landscapes that were highly valued for the experiences they provided (such as Birkenhead Park in Liverpool, England). Olmsted was named chair of the Yosemite commission tasked with preparing a plan for the newly granted park and served as the author of the commission's 1865 report. It is no coincidence that the principal planner for both Central Park and Yosemite Valley was the landscape architect, Frederick Law Olmsted, Sr., who wrote 'It is a responsibility of government, to withhold ... from the grasp of individuals, all places favourable in scenery to the recreation of the mind and body.' (Olmsted 1865 cited in Diamant et al. in press, 35)

Olmsted and others asserted that experience of spectacular scenic landscapes was beneficial to individuals and to society. 'For Olmsted, such experiences were necessary to human health and well-being; if government did not act to enhance and preserve such places and make them available to a visiting public, it would have failed in its duty to assure that all people had the opportunity to lead fulfilled lives.' (Diamant et al. in press, 8) This responsibility of government was particularly important in the context of the American Civil War (1861-1865). Creating parks, 

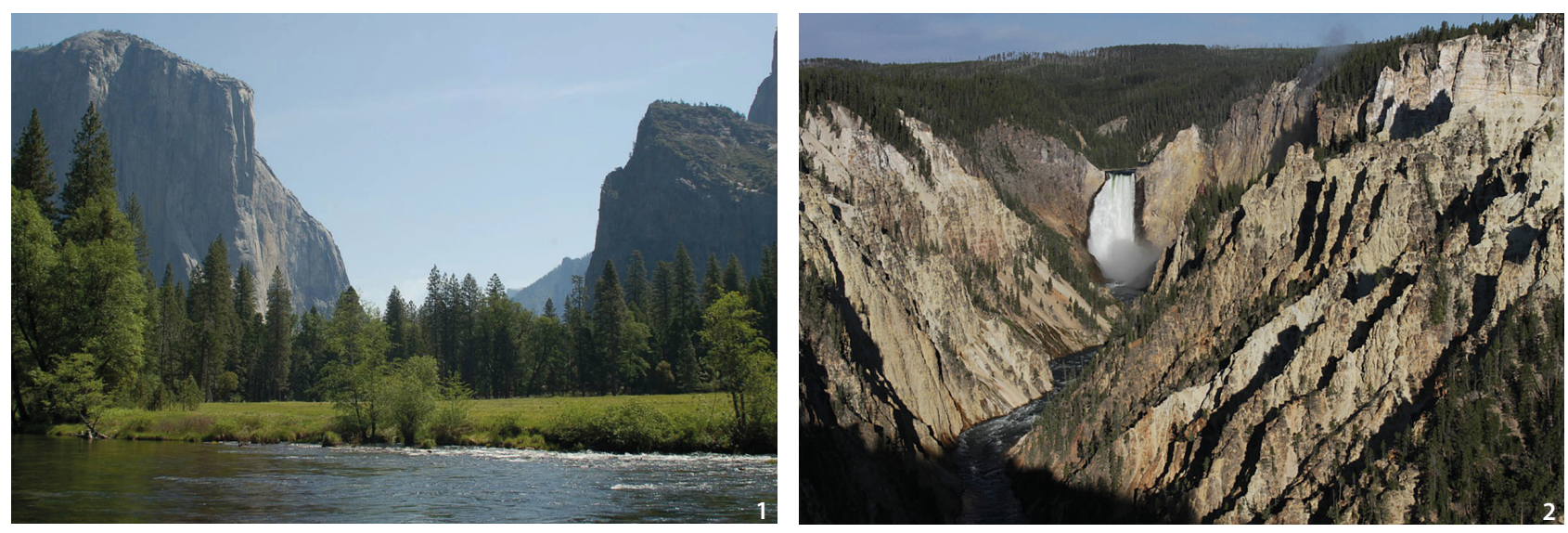

Figure 1 Merced River and Yosemite Valley, the first area set aside in 1864, Yosemite National Park (Source: National Park Service). Figure 2 The scenic Lower Yellowstone Falls in Yellowstone National Park (Source: National Park Service).

such as Yosemite, was an important part of a larger postwar national government agenda to redefine and expand the rewards of American citizenship. The Yosemite Act was enacted alongside other policy initiatives by the Lincoln administration which also provided public benefits including homesteading, building the transcontinental railroad, establishing a national system of colleges, and others that would transform the American government. It can also be argued that public parks were an expression of national unity and progress (Runte 1997). The idea that a modern national state had a requisite set of institutions for its citizens-including national parks-continued to be reinforced. By the 1890s, the idea of setting aside public land was considered by civic leaders ${ }^{2}$ to be a benefit to society just as 'the library holds books and the museum holds art, for the use and enjoyment of the public' (Eliot 1890, 117-118) (Figure 1).

\section{Yellowstone and Other Scenic National Parks}

The legislation that established Yellowstone in 1872, using the Yosemite Act as a template, dedicated over 2 million acres of the public domain 'as a public park or pleasuring ground for the benefit and enjoyment of the people' and set a precedent for other reserves under federal jurisdiction (Mackintosh 2005, 12-13). In addition to borrowing text from the Yosemite Act, Yellowstone and its successor parks were selected for their spectacular scenery such as Sequoia and General Grant followed by Mount Rainier in 1899 (Mackintosh 2005). Nine more scenic parks were established between 1900 and 1916 including Crater Lake, Glacier, Rocky Mountain and Hawai'i. While this succession of national park designations appears to indicate that it was easily accomplished, in reality, each park required long and vigorous campaigns by their supporters, often including western railroads looking for additional destinations for travellers (Figure 2).

\section{Expanding Values beyond Scenery: Protecting Landscapes with Antiquities}

During the 1880s and 1890s, while scenic national parks were being established, a separate concern arose for the protection of various archaeological sites including prehistoric cliff dwellings, historic pueblo remains and early missions in reaction to damage from vandalism and artifact hunting. In 1889, Congress authorised the President to reserve from settlement or sale the massive Casa Grande site in Arizona and three years later, President Benjamin Harrison created the Casa Grande Ruin Reservation (Mackintosh 2005). Even so, concerns for protection of many other archaeological sites continued and in 1906 the Antiquities Act was signed into law by President Theodore Roosevelt. This Act gave the US President the authority to reserve 'historic landmarks, historic and prehistoric structures, and other objects of historic or scientific interest' on lands owned or controlled by the US as 'national monuments' (Antiquities Act, quoted in Mackintosh 2005, 15).

The Antiquities Act was a significant landmark in national park history by recognising that 'preservation of historic, archaeological, and other scientific sites on lands controlled by the federal government was indeed a federal responsibility' (Richard Sellars quoted in Diamant et al. in press, 90). The recognition of landscapes with cultural significance extended the concept of national parks beyond those with spectacular scenery, opening the way for consideration of other types of landscape values. The authority of the Antiquities Act was used by President Theodore Roosevelt to proclaim 18 national monuments; the first was Devil's Tower, followed by El Morro, Montezuma's 


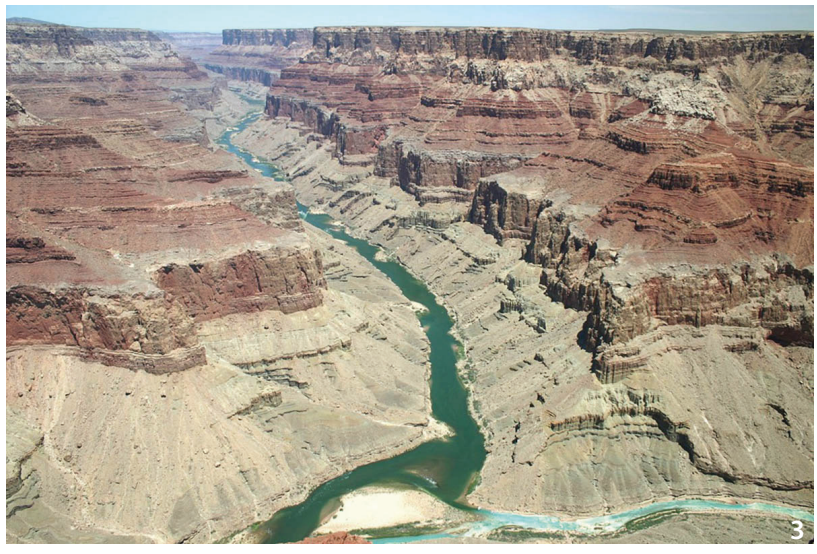

Figure 3 View of the Colorado River flowing through Grand Canyon National Park (Source: National Park Service).

Castle and Petrified Forest. In 1908, using a liberal definition of 'objects of scientific interest' President Roosevelt also designated part of the Grand Canyon a national monument. By the beginning of the $20^{\text {th }}$ century, US Presidents had proclaimed more than 100 national monuments (Mackintosh 2005) (Figure 3).

\section{Unifying the Parks as a National System}

By 1916, there were 37 National Parks and National Monuments and while the responsibility rested with the Department of the Interior, there was limited capacity for oversight and management. As a result, there were many management challenges-some ended up being referred to Congress for resolution and other times the US Army was asked to intervene. Frederick Law Olmsted, Jr., following in his father's footsteps, wrote that 'The present situation in regard to the national parks is very bad... acts of Congress... [have] not provided any orderly or efficient means of safeguarding the parks' (Olmsted quoted in Diamant et al. in press, 84). By 1911, the administration of President Howard Taft indicated their support for establishing a professional park bureau within the Department of the Interior. Then in 1913 Congress approved the polarising proposal to dam the Hetch Hetchy valley in Yosemite National Park for San Francisco's water supply. Ironically, this decision, a major setback for park protection, ultimately served as a catalyst for the creation of a US National Park Service (NPS) and for the National Park System (Diamant et al. in press). The debate over Hetch Hetchy mobilised park advocates across the country and convinced members of Congress that there was a need for a national park bureau to manage these types of controversies.

While the legislation to create a NPS had many contributors one of the most influential was Frederick Law Olmsted, Jr.. Drawing on language in the Antiquities Act and Olmsted, Sr's 1865 Yosemite Report, Olmsted, Jr. drafted the key phrase, describing the purpose of the new bureau:

to conserve the scenery and the natural and historic objects and the wild life therein and to provide for the enjoyment of the same in such manner and by such means as will leave them unimpaired for the enjoyment of future generations' (NPS Organic Act 1916 quoted in Mackintosh 2005, 21).

It is important to note that Olmsted, Jr. included the word 'historic' (as did the Antiquities Act), ensuring that landscapes with historic value would be considered as national parks as well as national monuments (Diamant et al. in press).

In addition to establishing the NPS, there was a clear intention in the NPS Organic Act to create a unified system of national parks. It was not until 1970, that Congress more clearly described the National Park System:

... These areas though distinct in character, are united through their interrelated purposes and resources into one national park system as cumulative expressions of a single national heritage; that, individually and collectively, these areas derive increased national dignity and recognition of their superb environmental quality through their inclusion jointly with each in one national park system preserved and managed for the benefit and inspiration of all the people of the United States (General Authorities Act of 1970 quoted in Diamant et al. in press, 108).

After establishment of the NPS, 25 additional natural areas were designated by 1933 including, Denali (originally called Mt. McKinley) in Alaska, Acadia in Maine, the Badlands in South Dakota and Isle Royale in Michigan. Seven significant prehistoric areas were also designated including Canyon de Chelly, homeland of the Navajo people, to be co-managed by the Navajo nation and the NPS (Lee 1972; Manning et al. 2016).

\section{Recognising Places with Historic Value}

By the early 1930s, for the first time, historic sitesGeorge Washington Birthplace, Colonial National Park, Yorktown and Morristown-were designated in the populated eastern part of the US in response to a popular nationalist design movement known as Colonial Revival. Several of the sites were located near Williamsburg, 


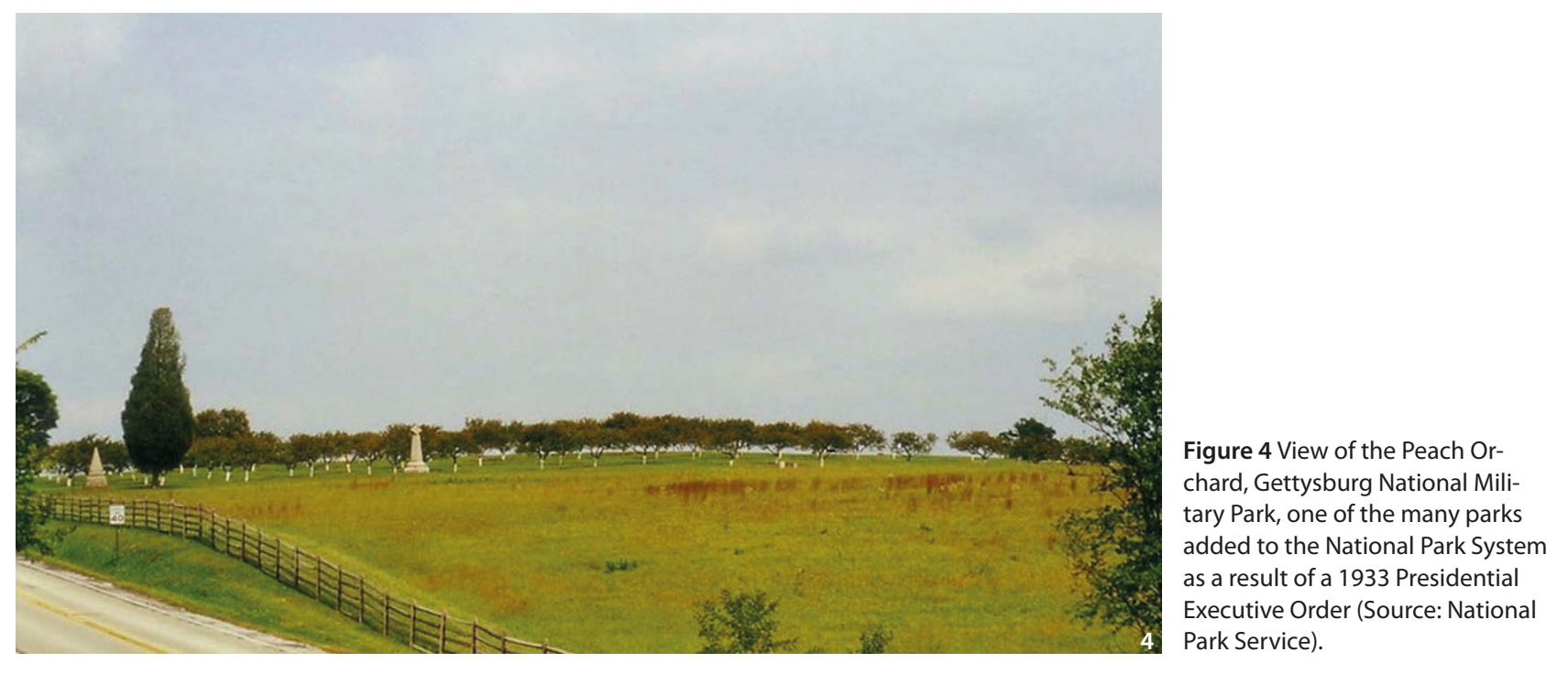

Virginia, where a significant private historic preservation project had been occurring for years at a Colonial Capital site (Hosmer 1980). This conservation project influenced NPS use of landscape archaeology and also advanced new ideas about historic reconstruction and interpretation of historic sites, including landscapes. Within this context, the NPS was well positioned to expand work in historic preservation and manage a growing number of historic sites.

In 1933, President Franklin D. Roosevelt, at the recommendation of NPS Director Horace Albright, signed an Executive Order that consolidated many existing parks under the management of the NPS. Roosevelt's Executive Order moved parks and national monuments of Washington, D.C., national cemeteries and national battlefields from the War Department, as well as the national monuments managed by the US Forest Service all under the NPS. This reorganisation 'was arguably the most significant event in the evolution of the National Park System ... [as] there was now a single system of federal parklands, truly national in scope, embracing historic as well as natural places' (Mackintosh 2005, 28). At the end of this reorganisation, there were 137 parks in the National Park System across the country (Lee 1972, footnote 1); many of the historic areas, and perhaps even some of the natural areas, would today be considered cultural landscapes. 'With the reorganisation, historic preservation became a major responsibility of the National Park Service.' (Mackintosh 2005, 51) (Figure 4)

Two years later, in 1935, Congress passed the Historic Sites Act designating the NPS as the lead federal agency in the nation for historic preservation, reinforcing the NPS role described in the Antiquities Act. The Act begins by declaring 'a national policy to preserve for public use historic sites, building and objects of national significance for the inspiration and benefit of the people of the United States' (quoted in Mackintosh 2005, 51). To implement this policy, the NPS surveyed historic properties to identify those significant in US history and provided federal assistance to historical properties (Mackintosh 2005, 51). This was an important expansion of the role of the NPS in historic preservation beyond the management of the National Park System.

Concurrently, there was a federal effort to professionally document historic buildings and landscapes. Although historic garden and historic landscape research had been underway in the NPS as early as 1918 (Goetcheus and Page, 2000, xi), in 1935, the Historic American Buildings Survey (HABS) and the Historic American Landscapes and Garden Project (HALGP) were established. Both programs established professional standards for measuring, drawing, photographing, conducting historic research and writing about historic structures, landscapes and properties; both programs still exist today ${ }^{3}$.

\section{Emergence of Natural Values}

Aside from all the work being done with historic sites after the 1933 reorganisation, places with natural resource values were also being considered as national parks. After much debate, in 1934, Everglades National Park, a rich ecological system threatened by drainage and other development projects, was authorised (Lee 1972). Because of the unprecedented recognition of natural values and the southeast location for this proposed park, there were several field visits organised including one that Olmsted, Jr. led on behalf of the National Parks Association, the 
principal park advocacy group that eventually spearheaded the successful effort for Everglades National Park (Runte 1997). Park advocates argued that although the Everglades did not have the spectacular scenery of the earlier western parks-still considered by many to be a requirement for designation-it did have a different kind of beauty, a 'sense of remoteness' and 'pristine wilderness' and also abundant wild life (Runte 1997, 134). Passage of this legislation was viewed as a major victory for conservation as it set a precedent for 'natural ecological relations' what they termed 'complete conservation' as the objective for a national park (Runte 1997, 135-136). Clearly, there was a search for new language to express another type of value conveyed by national parks. With this as a precedent, the authorisation of Cape Hatteras National Seashore in 1937 used some of the same arguments related to 'a primitive wilderness' in the justification of park values.

\section{Expansion into Recreation}

During the Depression (1929-1941) new terms came into use in the NPS-recreation, land planning and state cooperation (Lee 1972). Many federal programs developed to keep society and the economy stable during the Depression also afforded an opportunity to create new parks and undertake large land planning projects in cooperation with state governments to benefit local communities. Although the onset of World War II impacted the NPS through lack of funds, after the war there was a dynamic period of reinvestment in parks and park-making driven by population growth, expanded leisure time, and the desire to provide more recreation close to home. In 1956, a 10-year development program for the NPS, coined as 'Mission 66', was developed to build new facilities at numerous national parks across the country in response to rising post war recreational use. Further, a 1962 report of the Outdoor Recreation Resource Review Commission (ORRRC) reconfirmed that recreational planning was desperately needed, not just at the national level, but also at state and local levels as well (ORRRC 1962).

Just as the nation turned to the idea of public parks as unifying places after the Civil War, in the post-World War II economic expansion of the 1950s and 1960s, there was an increased demand for a national park experience near to existing population centres. As a result, several different types of designations were created, including National Seashores, National Parkways, and National Recreation Areas. While many of the early western national parks had been carved out of lands already in public ownership, in the post-war era, new parks were proposed in more populated regions that were already claimed by private as well as public owners. Cape Cod National Seashore on the Eastern Seaboard provided an early test of this new kind of park developed in an already lived-in landscape (Manning et al. 2016). The 40-mile strip of Atlantic beaches, dunes, and wetlands included parts of six communities and hundreds of privately-owned buildings. The park boundaries were authorised with the recognition that ownership of the 43,500 acres would remain a mix of federal, state, municipal and private landowners. To address the issues of mixed ownership, the authorising legislation contained a number of innovations to mesh the new park presence with the existing communities. Under what became known as the 'Cape Cod formula', the NPS was prohibited from condemning private improved property if the local governments adopted land use controls that were consistent with the park's purpose. This approach preserved the cultural landscape of fishing villages and summer cottages while also appeasing local property owners concerned about forced resettlement. Another innovation in the Cape Cod legislation was the establishment of a park advisory commission to give the local community and the park an ongoing forum (Barrett 2003) (Figure 5).

\section{Ramping Up Environmental Awareness and His- toric Preservation}

The 1960s witnessed a growing public concern with protecting the environment in the face of mounting evidence of air and water pollution, use of pesticides and the impact of development on landscapes including in and adjacent to national parks (Shabecoff 2003). In response, a social and environmental movement advocated reforms. In this context, in 1963, a Department of the Interior Advisory Board on Wildlife Management, chaired by A. Starker Leopold, a distinguished professor at University of California Berkeley, released a report 'Wildlife Management in the National Parks' calling for a management shift to ecosystem management and wilderness conservation (Runte 1997). Soon after, in 1964, the U.S. Congress passed the Wilderness Act that defined 'wilderness' as 'an area where the earth and its community of life are untrammeled by man, where man himself is a visitor who does not remain' (The Wilderness Act of 1964). The Wilderness Act directed the Department of the Interior to review areas in the National Park System for wilderness designation and to maintain the wilderness character of those areas designated as wilderness. By 2005, the NPS review had confirmed more than half the NPS lands as wilderness and as 


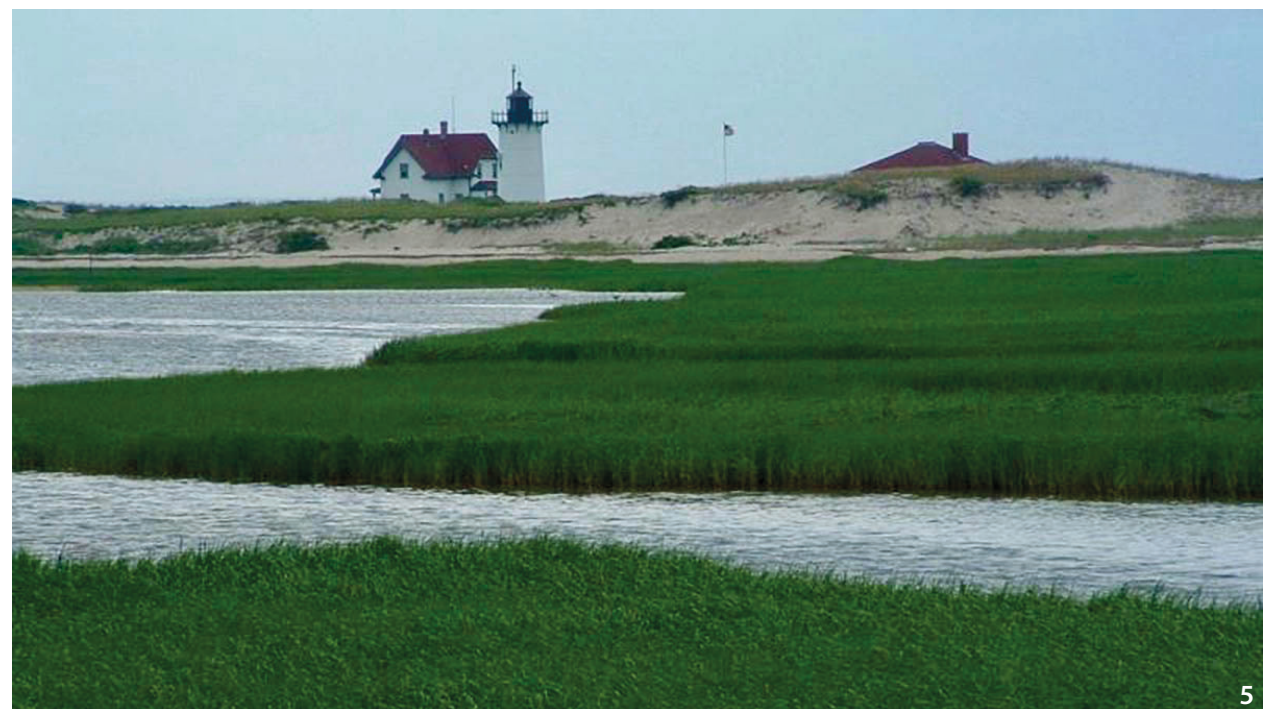

Figure 5 Cape Cod National Seashore, a recreational landscape representing one of the first livedin landscapes in the national park system (Source: National Park Service). of 2017, this percentage remains the same (Mackintosh 2005; Landres et al. 2017).

Only two years after the passing of the Wilderness Act, the serious impact of massive federal transportation projects and the physical devastation of urban renewal on the built environment triggered another national movement, one to preserve the nation's cultural heritage. In early 1966, a committee under the auspices the U.S. Conference of Mayors travelled to Europe to learn about preservation strategies from other countries and adapt them to the U.S. (U.S. Conference of Mayors, Special Committee on Historic Preservation 1966). Their report, With Heritage So Rich, strongly advocated for recognition and conservation of places with historic values and spoke eloquently of the depth and diversity of historical heritage, the mounting dangers to its preservation, and the need for new and broadened national preservation policies and programs. That report directly influenced the U.S. Congress to pass the National Historic Preservation Act of 1966. The Act not only directed the NPS to lead the nation in guiding historic preservation both within and beyond national parks, but also created programs to assist local, state and other federal agencies with their preservation responsibilities, formal partnerships between states and local governments, and standards for evaluating historic significance, reinforcing and extending the NPS role under the 1935 Historic Sites Act. Importantly, this Act also required national parks to inventory all historic resources and consider effects of management actions on historic resources including those located in wilderness areas.

Given these two potentially conflicting mandates to conserve wilderness and protect cultural heritage, it became important to provide guidance for national park managers to access the range of values present. Using language in the Wilderness Act, qualities of wilderness character have been defined that include historic and cultural resources (Cowley et al. 2012; Landres et al. 2017). For example, at Lake Clark National Park and Preserve, the wilderness character narrative describes some historical cabins and archeological sites and the connection the Native American Dena'ina people have to Lake Clark Wilderness (Cowley et al. 2012). As this example demonstrates, to meet the requirements of the Wilderness Act and cultural resource protection laws, it is vital to work across disciplines and with associated indigenous and local communities in assessing the full spectrum of values conveyed in wilderness areas and in national parks. More broadly, designation of wilderness sparked an important debate about the concept and management strategies that continues today (Cronon 1995; Nelson and Callicott 2008; Denevan 2011). These discussions have contributed ideas to the scale for conservation and interlinkages of culture and nature; these new directions are further explored in the following sections on 'Scaling Up Landscape Conservation' and Culture-Nature Journeys in the 'Conclusion'.

\section{NPS Recognition of Cultural Landscapes}

Concern about the impact of urban redevelopment, also led to a growing appreciation of the importance of protecting the character and enhancing the quality of life in cities. In this context, in the late 1960s and early 1970s, many cities became interested in improving their longneglected municipally owned Olmsted designed urban parks. There was a growing awareness of the value of these parks as public amenities and as historic resources based on the significance of the work of Olmsted, Sr. and 
the Olmsted Brothers. Boston's Olmsted Park System and New York's Central Park became widely known landscape preservation success stories (Pressley 2014). Landscape architects hired to do historic urban park revitalisation were literally developing the field of landscape preservation, laying the foundation for the appreciation and conservation of cultural landscapes in the coming decades. The work led to developments in cultural landscape research and alliances between a variety of disciplines including landscape architecture, architecture, horticulture, history, geography and others. By the late 1970s, several professional preservation organisations had formed to encourage discourse on historic landscape preservation including The Association for Preservation Technology, the Alliance for Historic Landscape Preservation, the American Society of Landscape Architects Historic Landscapes professional subcommittee, and the National Association of Olmsted Parks. After a decade of advocacy, in 1979 the Frederick Law Olmsted National Historic Site was established, a clear and significant acknowledgement of the role of cultural landscapes in the NPS (Allen 2007). The NPS had leaders in the preservation field, such as NPS Chief Historical Architect Hugh Miller, who worked to advance landscape preservation efforts in the agency and were actively involved in these professional organisations. Professional staff was hired to lead historic preservation programs in Washington, D.C. and across the country, and by the late 1970s, the NPS began integrating cultural landscapes into the national government framework for historic preservation (Mitchell and Melnick 2012).

During the next two decades-1980s and 1990s_there was an increasingly sophisticated development of both theory and practice of the field of cultural landscapes in the U.S. and across the globe (Jacques 1995; Alanen and Melnick 2000; Mitchell et al. 2009; Goetcheus and Mitchell 2014). In the U.S., through management policies for national parks and technical guidance, the NPS provided key leadership in cultural landscape conservation. A series of National Register Bulletins provided guidance for evaluating and managing cultural landscapes, beginning in 1987 with a National Register Bulletin on Designed Historic Landscapes, followed by one on Rural Historic Districts, and later on traditional cultural properties (Keller and Keller 1987; McClelland et al. 1999; Parker and King 1990). The NPS also undertook development of a baseline Cultural Landscape Inventory (CLI), and created or revised National Register nominations that incorporated cultural landscape values. Through the 1990s, additional publications offered guidance on analysing, documenting, and protecting cultural landscapes, such as A Guide to Cultural Landscape Reports (Page et al. 1998). As a result, the quantity of cultural landscape research produced during the 1980s was fivefold that of the previous five decades; and the number of reports produced during the 1990s exceeded the total of reports since the first publication in 1918 (Goetcheus and Page 2000, x). By the late 1990s, the NPS recognition of 'cultural landscapes' was formalised in NPS Director's Order 28 on cultural resources (NPS 1998). Ultimately a body of work was created that continues to guide cultural landscape work. Today cultural landscapes are recognised as heritage resources in policy, and assessments such as CLI and Cultural Landscape Reports (CLRs) are integrated not only within the NPS but also in public and private practice.

During this same time period, the international cultural landscape community, through ICOMOS (International Council on Monuments and Sites) particularly the International Scientific Committee on Cultural Landscapes, IUCN (International Union for the Conservation of Nature), particularly the work on Protected Landscapes, and the UNESCO World Heritage Centre all supported international dialogue and added greatly to the cultural landscape body of knowledge and guidance (Jacques 1995; Brown et al. 2005; Mitchell et al. 2009). Recognition of cultural landscapes in the guidelines for implementation of the World Heritage Convention in 1992 was a particularly significant milestone (Jacques 1995; Mitchell et al. 2009).

\section{Scaling Up Landscape Conservation}

The inclusion of cultural landscapes as a type of heritage resource also ushered in new ideas about conservation. Building on the management experience of lived-in landscapes through partnerships, tested at Cape Cod National Seashore and other parks in the 1970s, the NPS proposed creating a system of National Reserves. These were envisioned as large regional park-like designations with multi-layered governmental partnerships connected by jointly prepared management plans. Under this scheme, local communities would provide land protection and there would be limited federal land acquisition (Barrett 2003). Ultimately, only a few reserves were created; the best known are Ebey's Landing National Reserve (1978) in Washington state and Pinelands Preserve (1978) in New Jersey. An important strategy for both of these reserves was a commitment to sustaining long-standing cultural traditions of resource use into the future; in Ebey's Landing it was agriculture uses and in the Pinelands, harvesting cranberries and other natural resources (Mahoney 2017). 
In the 1980s the expansion of the National Park System was slowed by changes in national policy that limited federal spending for parks. Even so, community demand for the NPS to play a role in conserving and interpreting landscape resources continued. In response, planners within the NPS developed a conceptual approach to preserve the cultural, natural, and recreational resources of a region while limiting federal involvement-and this culminated in the National Heritage Areas program. The concept drew upon the innovations of the 1960s and 1970s such as including many different property owners within the boundary, developing management plans in partnership with local communities, and valuing the place as a lived-in cultural landscape. Under this new strategy, the federal government would invest limited dollars to interpret and stabilise resources but the NPS was not responsible for day-to-day management of the resources. National Heritage Areas, while placed in the NPS portfolio, were not to be managed, staffed, or funded like a traditional national park.

The first national heritage area initiative, the Illinois and Michigan (I\&M) Canal National Heritage Corridor, was created by statute in 1984 'to protect and enhance the utilisation of the abundant cultural and natural resources in the I\&M Canal Corridor while at the same time providing opportunity for economic development' (Barrett 2003, 43). The 97-mile canal corridor was built in the mid- $19^{\text {th }}$ century to connect Lake Michigan to the Illinois River and on to the Mississippi via a long-used American Indian portage. Encompassing 1,067 units of local government, an active ship canal, and the remnants of the earlier 1848 canal, this new NPS designation displayed the scale and multijurisdictional approach that characterised almost all later national heritage areas. The new ideas of how communities can intersect and cooperate with the NPS have broad public appeal. Today there are 49 National Heritage Areas spread across the country from Florida to Alaska.

Importantly, the heritage area approach has a successful track record of conserving and interpreting resources that are too large and costly to be managed within the boundaries of a traditional national park. The program brings flexibility and cost effectiveness that adds value to the national park idea. For example, several national heritage areas are re-purposing disused canal systems and telling the story of agriculture. This approach offers an opportunity to place national parks in their regional cultural landscape context. As community-centred organisations, National Heritage Areas have the ability to tell powerful stories and serve as centres of cultural renewal (Barrett 2013).

These new kinds of protected areas and programs pioneered important concepts that have direct applicability to conserving the country's cultural landscapes. These ideas include recognising significant heritage resources that are found within large landscapes, adopting new partnership forms of governance, limiting and leveraging the federal investment and control, and adopting community social and economic vitality as a goal for these types of park designations (Barrett 2018) (Figure 6).

More recently the conservation field has now adopted some of these ideas to work at much larger spatial scales to more effectively match the scope of the challenges and the scale of ecosystems and cultural systems (Network for Landscape Conservation n.d.; NPS 2014; Mitchell et al. 2015; Mitchell 2016) Many cultural landscapes and ecosystems in and adjacent to parks are being adversely impacted by large scale impacts such as mineral extraction, urban expansion, air and water pollution, and the effects of climate change (NPS 2014; Sauvajot 2016). Since many of these threats transcend political and disciplinary boundaries, the NPS has responded with an initiative to scale up the protection of resources by working closely with partners across the surrounding region from working landscapes to wilderness areas (Network for Landscape Conservation n.d.; NPS 2014). This new direction for conservation responds to societal needs and values yet again refashioning ideas about national parks.

\section{Conclusions: Lessons in Park-Making}

From its beginnings in Yosemite Valley in the mid- $19^{\text {th }}$ century, the U.S. National Park System has continued to grow and diversify. The annotated chronology of park-making in this paper demonstrates that the type of landscapes included in the system has shifted over time in response to changing societal values and needs. Olmsted and others argued for the importance of national parks for the wellbeing of citizenary. Over time, the National Park System has matured into an important civic institution that continues to serve the public purposes of conservation and demonstrates the important role of government acting on behalf of its citizens. These ideas continue to animate each park designation and the stewardship of national parks by the National Park Service. In anticipation of the NPS centennial in 2016, a National Parks Second Century Commission was convened to reflect on the past and future of the NPS and the park system it serves. The Commission's report noted that not only have national parks served their original purpose, but today 'serve purposes and provide benefits far broader than were envisioned for them a century ago' (National Parks Second Century Commission 2009). 


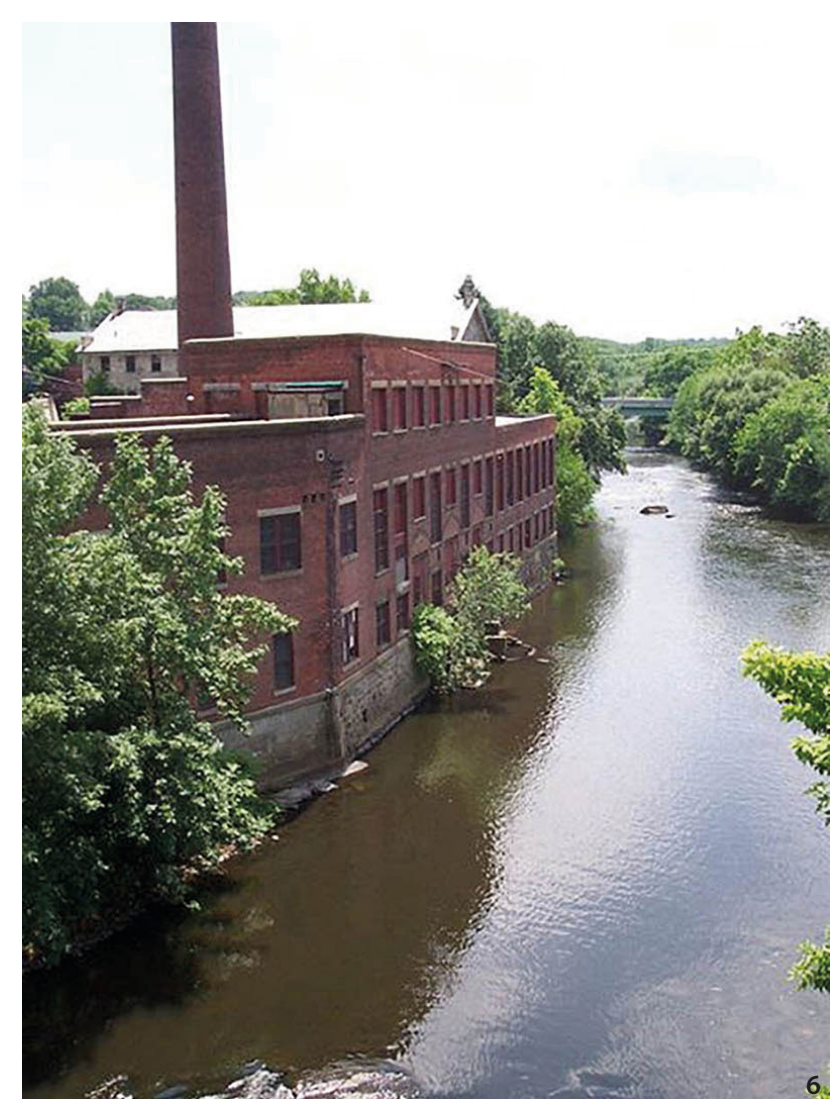

Figure 6 Former textile mill along the Blackstone River in the Blackstone River Valley National Heritage Corridor (Source: U.S. National Park Service).

Inclusion of cultural landscapes as part of the National Park System illustrates how an expanded recognition of multiple values of national parks mirrors the rich heritage of the country and positions the system to remain relevant, contribute knowledge, and advance innovation. Cultural landscapes, created by long-standing relationships between people and their environment, can have important tangible and intangible heritage, interlink with natural values, and also provide important benefits for society through lessons in adaptation, sustainability and resilience (Taylor et al. 2015). In addition, the inclusion of lived-in cultural landscapes has also raised management challenges that led to the fashioning of innovative new partnership strategies. Parks with such partnerships and shared governance engage local communities and interest groups bringing both new constituencies and more understanding and support for conservation of heritage values (Manning et al. 2016). More recently, a regional landscape approach has emerged as a strategy for addressing large scale challenges, integrating cultural and natural heritage across boundaries, and collaborating with multiple partners (Network for Landscape Conservation n.d.; NPS 2014).
Finally, it is important to recognise that the National Park System has benefitted greatly from the knowledge and experience of park-making practices from around the world, lessons that have helped to shape the creation, planning, and management of U.S. parks and protected areas. This paper includes examples of important contributions drawn from other countries that benefited the U.S. National Park System. Olmsted drew ideas from the large picturesque parks in England, others found inspiration for large landscape corridors from 'green line parks', and the tour of the historic sites of Europe that laid the foundation for the influential report, With Heritage so Rich that resulted in the passage of the National Historic Preservation Act in 1966. These trans-boundary exchanges continue to this day. ICOMOS, through its Scientific Committee on Cultural Landscapes, and IUCN World Commission on Protected Areas Specialist Groups on Protected Landscapes and on Spiritual and Cultural Values provide an on-going forum. A current international initiative, co-led by ICOMOS and IUCN, has launched a series of international discussions, termed Culture-Nature Journeys, to reflect on the critical importance of bridging the culturenature divide in conservation (Mitchell et al. 2017). This initiative was launched in response to the growing evidence that lasting conservation for landscapes/seascapes depends on inter-linking cultural and natural heritage in planning and management (Leitão et al. 2017).

Ultimately, it is the complexity of the National Park System, the tangible and intangible heritage and the values that it represents, and the people who work on stewardship that will continue this legacy over time continuing to respond and adapt to social change. In making a case for the diversity of the National Park System, the National Park Second Century Commission affirmed that changes and growth in the system encompass a more complete representation of our rich and diverse cultural and natural history that reflects a growing awareness that parks play an important role in building civil society as they are 'community-builders, creating an enlightened society committed to a more sustainable world' (National Parks Second Century Commission 2009, 16 and 21).

\section{Notes}

1. In the U.S., 'conservation' is generally associated with natural systems and is not commonly used in reference to cultural resources; preservation is the term used to address cultural resource conservation. In this paper we have adopted the term 'conservation' as used by the broader international community for a number 
of reasons including the recognition that landscapes are at the interface of nature and culture. Secondly, we use the term 'cultural landscapes' in the U.S. as a broad rubric to include rural historic districts, designed historic landscapes, historic sites, ethnographic landscapes and traditional sites, and to refer to large landscapes with a regional identity. Most of the ideas and examples in this paper refer to landscapes that have evolved through decades and centuries of human use and decisions - and many that continue to evolve.

2. Civic leaders such as horticulturalist Charles Sprague Sargent and landscape architect Charles Eliot who was a protégé and partner of Frederick Law Olmsted, Sr. and Olmsted's son, John Charles.

3. HALGP only lasted from 1935-1938, yet was resurrected as the Historic American Landscapes Survey (HALS) in 2000.

\section{References}

Alanen, Arnold Robert, and Robert Z. Melnick, eds. 2000. Preserving Cultural Landscapes in America. Baltimore: Johns Hopkins University Press.

Allen, David Grayson. 2007. The Olmsted National Historic Site and the Growth of Historic Landscape Preservation. Lebanon, NH: Northeastern University Press.

Barrett, Brenda. 2003. "Roots for the National Heritage Area Family Tree." The George Wright Forum 20 (2): 41-49.

Barrett, Brenda. 2013. "National Heritage Areas Evaluating Past Practice as a Foundation for the Future." Proceedings of Fabos Conference on Greenways. Amherst: University of Massachusetts.

Barrett, Brenda. 2018. "New Horizons for National Heritage Areas: An Opportunity to Scale Up Historic Preservation." In Creating Historic Preservation in the 21st Century, edited by Richard D. Wagner and de Teel Patterson Tiller, 97-111. Cambridge: Cambridge Scholars Publishing.

Brown, Jessica, Nora Mitchell and Michael Beresford. 2005. The Protected Landscape Approach: Linking Nature, Culture and Community. Gland: IUCN, World Commission on Protected Areas.

Cowley, Jill, Peter Landres, Melissa Memory, Doug Scott, and Adrienne Lindholm. 2012. "Integrating cultural resources and wilderness character." Park Science 28 (3): 29-33, 38.

Cronon, William. 1995. Uncommon Ground, Toward Reinventing Nature. New York and London: W.W. Norton \& Company.

Diamant, Rolf, Ethan Carr, Lauren Meier, and Shannon Ricchetti. In press. The Olmsteds and the National Park
System Historic Resource Study. Washington, D.C.: US Department of the Interior, National Park Service, Organization of American Historians, and Frederick Law Olmsted National Historic Site.

Denevan, Wiliam Maxfield. October 2011. “The 'Pristine Myth' Revisited." The Geographical Review 101 (4): 576591.

Eliot, Charles. March 5, 1890. “The Waverly Oaks.” Garden and Forest, 117-118.

Goetcheus, Cari and Nora Mitchell. 2014. “The Venice Charter and Cultural Landscapes: Evolution of Heritage Concepts and Conservation over Time." Change over Time 4 (2): 338-357.

Goetcheus, Cari and Robert Page, eds. 2000. Cultural Landscape Bibliography: Resources in the National Park System. Washington, D.C.: U.S. Department of the Interior, National Park Service, Cultural Resources Stewardship and Partnerships, Park Historic Structures and Cultural Landscape Program.

Historic Sites Act of 1935 (16 U.S.C. sections 461-467).

Hosmer, Charles Bridgham, Jr. 1980. "Preservation Comes of Age: From Williamsburg to the National Trust, 19261949." Bulletin of the Association for Preservation Technology 12 (3): 20-27.

Jacques, David. 1995. “The Rise of Cultural Landscapes." International Journal of Heritage Studies 1 (2): 91-101.

Keller, Timothy, and Keller Genevieve. 1987. National Register Bulletin 18: How to Evaluate and Nominate Designed Historic Landscapes. Washington, DC: U.S. Department of the Interior, National Park Service.

Landres, Peter, Chris Barns, Steve Boutcher, Tim Devine, Peter Dratch, Adrienne Lindholm, Linda Merigliano, Nancy Roeper, and Emily Simpson. 2015. Keeping It Wild 2: An Updated Inter-agency Strategy to Monitor Trends in Wilderness Character Across the National Wilderness Preservation System. Gen. Tech. Rep. RMRS-GTR-340. Fort Collins, Colorado: U.S. Department of Agriculture, Forest Service, Rocky Mountain Research Station.

Lee, Ronald F. 1972. Family Tree of the National Park System: A Chart with Accompanying Text Designed to Illustrate the Growth of the National Park System 1872-1972. Philadelphia: Eastern National Park and Monument Association. Accessed 30 June 2018. https://www.nps.gov/parkhistory/ online_books/lee2/index.htm

Leitão, Leticia, Gwenaëlle Bourdin, Tim Badman, and Leanna Wigboldus. 2017. "Connecting Practice Phase II: Final Report ICOMOS/IUCN." Accessed 16 July 2018. http://openarchive.icomos.org/1841

Mackintosh, Barry. 2005. The National Parks: Shaping the 
System. Washington, D.C.: U.S. Department of the Interior, National Park Service. Accessed 7 July 2018. https:// www.nps.gov/parkhistory/online_books/shaping/index. htm

Mahoney, Eleanor. April 2017. "What is in a (Public Lands) Name?” Living Landscape Observer. Accessed 7 July 2018. http://livinglandscapeobserver.net/233128

Manning, Robert, Rolf Diamant, Nora Mitchell, and David Harmon, eds. 2016. A Thinking Person's Guide to America's National Parks. New York: George Braziller Publishers.

McClelland, Linda Flint, Keller Timothy, Keller Genevieve, and Melnick Robert. 1999. National Register Bulletin 30: Guidelines for Evaluating and Documenting Rural Historic Landscapes. Washington, DC: National Park Service.

Mitchell, Brent, ed. 2016. "Scaling Up: Landscape-scale Conservation in North America." The George Wright Forum 22 (2). Accessed 13 July 2018. http://www.georgewright. org/332.pdf

Mitchell, Brent, Brenda Barrett, and Tony Hiss, eds. 2015. "Expanding Horizons: Highlights from the National Workshop on Large Landscape Conservation.” Accessed 13 July 2018. http://landscapeconservation.org/wp-content/uploads/2018/01/ExpandingHorizons_Feb11.pdf

Mitchell, Nora, Jessica Brown, and Brenda Barrett. 2017. "Nature-Culture Journeys: Exploring Shared Terrain." The George Wright Forum 34 (2). Accessed 13 July 2018. http://www.georgewright.org/342.pdf

Mitchell, Nora, and Robert Melnick. 2012. "Shifting Paradigms: New Directions in Cultural Landscape Conservation for a Twenty-first Century America." In Managing Cultural Landscapes, edited by Ken Taylor and Jane Lennon, 232-252. London: Routledge.

Mitchell, Nora, Mechtild Rössler, and Pierre-Marie Tricaud, authors/editors. 2009. "World Heritage Cultural Landscapes: A Handbook for Conservation and Management." World Heritage Papers 26. Paris: UNESCO.

National Historic Preservation Act of 1966 (P.L. 89-665 as amended).

National Park Service Act of August 25, 1916 (P.L. 64-235).

NPS (National Park Service). 1998. Director's Order 28 Cultural Resource Management. Washington, D.C.: U.S. Department of the Interior, National Park Service. Accessed 3 July 2018. https://www.nps.gov/parkhistory/online_ books/nps28/28contents.htm

NPS (National Park Service). 2014. Scaling up: Collaborative Approaches to Large Landscape Conservation. Annapolis MD and Woodstock VT: National Park Service. Accessed 14 July 2018. https://www.nps.gov/orgs/1412/upload/
Scaling-Up-2014-508.pdf

National Parks Second Century Commission. 2009. Advancing the National Park Idea. Washington D.C.: National Parks and Conservation Association.

Nelson, Michael P., and J. Baird Callicott, eds. 2008. The Wilderness Debate Rages On: Continuing the Great New Wilderness Debate. Georgia,: The University of Georgia Press.

Network for Landscape Conservation. Accessed 13 July 2018. http://landscapeconservation.org

Olmsted, Frederick Law. 1865. "Yosemite and the Mariposa Grove." Reprinted by the Yosemite Association 1995.

ORRRC (Outdoor Recreation Resources Review Commission). 1962. Outdoor Recreation for America - a Report to the President and to the Congress by the Outdoor Recreation Resources Review Commission. Washington, D.C.: The Commission. Accessed 7 July 2018. https://www.nps. gov/parkhistory/online_books/anps/anps_5d.htm

Page, Robert, Cathy Gilbert, and Susan Dolan. 1998. A Guide to Cultural Landscape Reports: Contents, Process, and Techniques. Washington, DC: U.S. Department of the Interior, National Park Service.

Parker, P., and T. F. King. 1990, revised in 1998. National Register Bulletin 38: Guidelines for Evaluating and Nominating Traditional Cultural Properties. Washington, DC: U.S. Department of the Interior, National Park Service.

Pressley, Marion. 2014. “Oral History Interview.” Interview by Cari Goetcheus in Boston, Massachusetts, 2014.

Runte, Alfred. 1997. National Parks, The American Experience. Lincoln and London: University of Nebraska Press.

Sauer, Carl Ortwin. 1925. "The Morphology of Landscape." University of California Publications in Geography 2 (2): 19-53.

Sauvajot, Raymond Marc. 2016. "National Parks and the Scaling Up Imperative." The George Wright Forum 33 (2): 145-148.

Shabecoff, Phillip. 2003. A Fierce Green Fire: The American Environmental Movement. Washington, D.C.: Island Press.

Taylor, Ken, Archer St Clair Harvey, and Nora Mitchell, eds. 2015. Conserving Cultural Landscapes: Challenges and New Directions. London: Routledge.

The Antiquities Act of 1906 (54 USC Ch 3203).

The Wilderness Act of 1964 (Public Law 88-577).

U.S. Conference of Mayors, Special Committee on Historic Preservation. 1966. With Heritage So Rich. New York: Random House.

Yosemite Valley Grant Act. 1864. (16 U.S.C., sec. 48, chapter 1) Accessed 15 July 2018. https://www.nps.gov/featurecontent/yose/anniversary/timeline/in-1864/index.html 